\title{
Effects of slow-release urea and rumen-protected methionine and histidine on mammalian target of rapamycin (mTOR) signaling and ubiquitin proteasome-related gene expression in skeletal muscle of dairy cows
}

\author{
H. Sadri, ${ }^{*} \dagger^{1}$ F. Giallongo, $\ddagger$ A. N. Hristov, $\ddagger$ J. Werner,, C. H. Lang,\# C. Parys, II B. Saremi,II and H. Sauerwein* \\ *Institute of Animal Science, Physiology and Hygiene Unit, University of Bonn, 53115 Bonn, Germany \\ †Department of Clinical Science, Faculty of Veterinary Medicine, University of Tabriz, 516616471 Tabriz, Iran \\ †Department of Animal Science, and \\ §Animal Resource Program, The Pennsylvania State University, University Park 16802 \\ \#Department of Cellular and Molecular Physiology, Penn State College of Medicine, Hershey, PA 17033 \\ \|Evonik Nutrition \& Care GmbH, Rodenbacher Chaussee 4, 63457 Hanau, Germany
}

\begin{abstract}
The mammalian target of rapamycin (mTOR) is a major regulator of protein synthesis, whereas the ubiquitin-proteasome system (UPS) is regarded as the main proteolytic pathway in skeletal muscle. The objective of the current study was to investigate the effects of slow-release urea and rumen-protected (RP) Met and His supplementation of a metabolizable protein (MP)deficient diet on the abundance of key components of the mTOR pathway and of the UPS in skeletal muscle of dairy cows. Sixty Holstein cows were blocked based on days in milk and milk yield and were randomly assigned within block to 1 of 5 diets in a 10-wk experiment (including the first 2 wk as covariate period) as follows: (1) MP-adequate diet (AMP; 107\% of MP requirements, based on the National Research Council requirements); (2) MP-deficient diet (DMP; $95 \%$ of MP requirements); (3) DMP supplemented with slowrelease urea (DMPU); (4) DMPU supplemented with RPMet (DMPUM); and (5) DMPUM supplemented with RPHis (DMPUMH). Muscle biopsies were collected from longissimus dorsi during the last week of the experiment. The mRNA abundance of key mTOR signaling genes was not affected by the treatments. The phosphorylated $(\mathrm{P})$-mTOR protein was or tended to be greater for DMP compared with DMPU and AMP, respectively. The P-mTOR protein in DMPUMH was decreased when compared against DMPUM. The P-ribosomal protein $\mathrm{S} 6$ tended to be increased by DMPUM compared with DMPU. The abundance of total-S6 was or tended to be greater for DMP compared with AMP and DMPU, respectively. The mRNA abundance of ubiquitin activating and conjugating enzymes was not
\end{abstract}

Received November 23, 2015.

Accepted April 6, 2016.

${ }^{1}$ Corresponding author: hsadri@uni-bonn.de affected by the treatments, whereas that of muscle ringfinger protein $1(M u R F-1)$ was greater in DMP than DMPU. The increased abundance of mTOR-associated signaling proteins and $M u R F-1$ mRNA abundance indicates a higher rate of protein turnover in muscle of DMP-fed cows. The reduced abundance of P-mTOR by supplementation of RPHis may suggest that His is likely partitioned to the mammary gland in favor of milk protein synthesis rather than to the skeletal muscle in dairy cows fed MP-deficient diets.

Key words: rumen-protected amino acid, mammalian target of rapamycin, ubiquitin-proteasome system, muscle, dairy cow

\section{INTRODUCTION}

Nitrogen excreted with animal feces or urine is one of the main pollutants from livestock operations, with a major contribution of urinary urea to emissions of ammonia (Lee et al., 2012) and nitrous oxide from cattle manure (US EPA, 2011). Reducing dietary protein levels has been shown as the most effective nutritional strategy to increase the efficiency of $\mathrm{N}$ use for milk protein synthesis and to decrease urinary $\mathrm{N}$ losses and, consequently, ammonia emissions from dairy farms (Huhtanen and Hristov, 2009; Aguerre et al., 2010; Hristov et al., 2011). In addition, further economic benefits can be attained by feeding lower protein rations due to decreased feed costs and improved farm profitability (Schwab and Ordway, 2004). Thus, interest is increasing in the use of rumen-protected (RP) limiting AA for high-producing dairy cows to compensate for MP deficiency in dairy cow diets (Hristov and Giallongo, 2014).

Skeletal muscle, the largest internal organ in mammals, plays a major role in maintaining AA homeostasis. It is the main labile source of AA in the body and can be broken down to provide free AA to support the immune response and anabolic processes including 
gluconeogenesis and protein synthesis in other organs (Lang et al., 2013). The functional integrity and quality of skeletal muscle is maintained through a continuous turnover of protein, resulting from both protein synthesis and protein degradation. The balance between both processes is controlled via several pathways, whereby the mammalian target of rapamycin (mTOR) and the ubiquitin-proteasome system (UPS) are considered as the major regulators of protein synthesis and protein degradation, respectively. Amino acids and insulin play key roles in the regulation of protein synthesis in muscle (Davis et al., 2010). Some studies suggest that mTOR integrates $\mathrm{AA}$ and insulin signals through multiple mechanisms including phosphorylation of ribosomal protein S6 kinase 1 (S6K1) and eukaryotic translation initiation factor $4 \mathrm{E}$ binding protein 1 (4E-BP1), both downstream effectors of mTOR regulating protein synthesis and cell growth (Proud, 2006; Davis et al., 2010). Protein degradation through UPS is highly regulated and muscle ring-finger protein 1 (MuRF-1) and atrogin-1, known as 2 major muscle-specific E3 ubiquitin ligases, are important components of the UPS (Glass, 2003; Nandi et al., 2006). Feeding a nutrient-restricted diet $\left(68.1 \%\right.$ of $\mathrm{NE}_{\mathrm{M}}$ and $86.7 \%$ of $\mathrm{MP}$ requirements) to Angus-Gelbvieh crossbred cows was associated with a downregulation of mTOR signaling and a higher amount of ubiquitinated proteins, suggesting a decrease in protein synthesis and enhanced protein degradation in muscle (Du et al., 2005). In the main experiment of this study (Giallongo et al., 2015), feeding a 5\% MPdeficient diet based on the NRC (2001) requirements did not decrease DMI and yields of milk and milk components; however, it increased or tended to increase plasma concentrations of 3-methylhistidine (3-MH; an indicator of myofibrillar protein breakdown) when compared with an MP-adequate diet and an MP-deficient diet supplemented with slow-release urea, respectively. In addition, the results from the main experiment demonstrated that cows receiving the MP-deficient diet had less BW gain than those fed MP-adequate diet or slowrelease urea and RPAA-supplemented diets (Giallongo et al., 2015).

We hypothesized that addition of slow-release urea or RPMet and RPHis to a MP-deficient diet (according to NRC, 2001) may also affect the regulation of specific signaling components in skeletal muscle in support of protein synthesis and decreased protein degradation. Therefore, we evaluated the effects of slow-release urea and RPMet and RPHis supplementation of a MPdeficient diet, according to NRC (2001) requirements, on expression of key factors of the mTOR pathway and UPS in skeletal muscle of dairy cows. Muscle samples together with comprehensive production data, including milk yield and composition and plasma and muscle
AA concentrations, were available from the main experiment (i.e., Giallongo et al., 2015).

\section{MATERIALS AND METHODS}

\section{Animals, Treatments, and Experimental Design}

The main experiment was conducted in the tiestall barn of The Pennsylvania State University's Dairy Teaching and Research Center. The experimental procedures were in accordance with the guidelines of the Animal Care and Use Committee at The Pennsylvania State University. Cows, experimental design, and treatments were described in detail by Giallongo et al. (2015). Briefly, the trial was conducted in 2 phases each consisting of 30 lactating Holstein cows. Phase 1 involved 5 primiparous and 25 multiparous cows and phase 2 involved 12 primiparous and 18 multiparous cows. Cows were blocked based on DIM and milk yield. Within block, cows were randomly assigned to 1 of 5 dietary treatments in a 10 -wk experiment (including a 2-wk covariate period, 2 wk of adaptation to the diets, and 6 wk of data collection): (1) MP-adequate diet [AMP; providing 107\% of MP requirements according to NRC (2001)]; (2) MP-deficient diet (DMP; providing $95 \%$ of MP requirements); (3) DMP supplemented with $0.4 \%$ (DM basis) of a slow-release urea source (DMPU; urea from Optigen, Alltech Inc., Nicholasville, KY; providing $92 \%$ of MP requirements); (4) DMPU supplemented with $30 \mathrm{~g}$ of RPMet/cow per day [DMPUM; RPMet from Mepron (RP DL-Met); Evonik Nutrition \& Care GmbH, Hanau, Germany; providing $96 \%$ of MP requirements]; and (5) DMPUM supplemented with $50 \mathrm{~g}$ of RPHis/cow per day (DMPUMH; experimental RP L-His. $\mathrm{HCl}$ product from Balchem Corp., New Hampton, NY; providing 95\% of MP requirements). Cows were fed a TMR (Table 1) twice daily and had free access to water. In both phases of the experiment the composition of the diets was the same. Cows received the RPAA supplements (RPMet and RPHis) once daily, top dressed with a small portion of the DMPU diet in the morning feeding.

\section{Tissue Sampling}

Muscle biopsies (longissimus dorsi) were collected from all 30 cows in phase 1 and from 15 (10 primiparous and 5 multiparous) randomly selected cows (3 cows/treatment) in phase 2 during the last week of the experiment (wk 8), as described in Giallongo et al. (2015). Due to personnel availability, only 15 cows (i.e., 3 cows/treatment) were randomly selected for muscle biopsies in phase 2 of the study. Tissue samples were snap-frozen in liquid nitrogen and stored at $-80^{\circ} \mathrm{C}$ until analysis. 
Table 1. Ingredient and chemical composition of the basal diets fed in the trial (Giallongo et al., 2015)

\begin{tabular}{|c|c|c|c|}
\hline \multirow[b]{2}{*}{ Item } & \multicolumn{3}{|c|}{ Diet, ${ }^{1}$ phase 1 and 2} \\
\hline & $\mathrm{AMP}$ & DMP & DMPU \\
\hline \multicolumn{4}{|l|}{ Ingredient, $\%$ of $\mathrm{DM}$} \\
\hline Corn silage $^{2}$ & 43.3 & 43.3 & 43.3 \\
\hline Grass hay $^{3}$ & 8.0 & 8.0 & 8.0 \\
\hline Cottonseed, hulls & 3.8 & 3.8 & 3.8 \\
\hline Forage & 55.1 & 55.1 & 55.1 \\
\hline Corn grain, ground & 9.9 & 14.9 & 14.5 \\
\hline Candy by-product meal ${ }^{4}$ & 6.0 & 6.0 & 6.0 \\
\hline Soybean seeds, whole, heated ${ }^{5}$ & 7.9 & 7.9 & 7.9 \\
\hline Canola meal, mechanically extracted ${ }^{6}$ & 8.0 & 8.0 & 8.0 \\
\hline SoyPLUS $^{7}$ & 7.0 & 2.0 & 2.0 \\
\hline Molasses $^{8}$ & 3.4 & 3.4 & 3.4 \\
\hline Optigen $^{9}$ & - & - & 0.4 \\
\hline Mineral/vitamin premix $^{10}$ & 2.7 & 2.7 & 2.7 \\
\hline \multicolumn{4}{|l|}{ Composition, $\%$ of DM (unless noted) } \\
\hline $\mathrm{CP}^{11,12}$ & 16.7 & 14.8 & 15.8 \\
\hline $\mathrm{RDP}^{13}$ & 9.2 & 8.6 & 9.7 \\
\hline $\mathrm{RUP}^{13}$ & 7.5 & 6.2 & 6.1 \\
\hline $\mathrm{NDF}^{11}$ & 31.4 & 30.8 & 30.8 \\
\hline $\mathrm{ADF}^{11}$ & $\begin{array}{l}01.4 \\
18.9\end{array}$ & 18.7 & 18.7 \\
\hline $\operatorname{Starch}^{11}$ & 25.7 & 29.1 & 28.8 \\
\hline $\mathrm{NE}_{\mathrm{L}}$, Mcal $/ \mathrm{kg}^{13}$ & 1.60 & 1.57 & 1.59 \\
\hline $\mathrm{NE}_{\mathrm{L}}$ balance, $\mathrm{Mcal} / \mathrm{d}^{13}$ & 3.24 & 3.12 & 1.81 \\
\hline $\mathrm{NFC}^{13}$ & 43.0 & 45.7 & 44.7 \\
\hline $\mathrm{Ca}^{11}$ & 0.65 & 0.63 & 0.63 \\
\hline $\mathrm{P}^{11}$ & 0.40 & 0.38 & 0.38 \\
\hline
\end{tabular}

${ }^{1} \mathrm{AMP}=\mathrm{MP}$-adequate diet; $\mathrm{DMP}=\mathrm{MP}$-deficient diet; $\mathrm{DMPU}=\mathrm{DMP}$ diet supplemented with Optigen (Alltech Inc., Nicholasville, KY). Two additional diets were fed in this study: DMPUM = DMPU diet supplemented with $30 \mathrm{~g}$ of rumen-protected Met/cow per day (Mepron; Evonik Industries AG, Hanau, Germany); and DMPUMH = DMPUM diet supplemented with $50 \mathrm{~g}$ of rumen-protected His/cow per day (Balchem Corp., New Hampton, NY).

${ }^{2}$ Corn silage was 45.1 and $41.3 \% \mathrm{DM}$ and contained (DM basis): 8.9 and $8.5 \% \mathrm{CP}, 39.1$ and $41.7 \%$ starch, and 37.5 and $32.1 \%$ NDF (phase 1 and 2, respectively).

${ }^{3}$ Grass hay was $86.2 \% \mathrm{DM}$ and (DM basis) $6.4 \% \mathrm{CP}$ and $73.5 \% \mathrm{NDF}$ (average of phase 1 and 2).

${ }^{4}$ Candy by-product meal (Graybill Processing, Elizabethtown, PA) contained (DM basis) $17 \%$ CP and $27.8 \%$ NDF (average of phase 1 and 2).

${ }^{5}$ Soybean seeds contained (DM basis) $40.0 \% \mathrm{CP}$ (average of phase 1 and 2).

${ }^{6}$ Canola meal contained (DM basis) $42.2 \%$ CP (average of phase 1 and 2 ).

${ }^{7}$ SoyPLUS (West Central Cooperative, Ralston, IA) contained (DM basis) 46.9\% CP (average of phase 1 and 2).

${ }^{8}$ Molasses (Westway Feed Products, Tomball, TX) contained (DM basis) $3.9 \% \mathrm{CP}$ and $66 \%$ total sugar.

${ }^{9}$ Optigen is a slow-release urea (Alltech Inc., Nicholasville, KY).

${ }^{10}$ The premix (Cargill Animal Nutrition, Cargill Inc., Roaring Spring, PA) contained (\%, as-is basis) trace mineral mix, 0.86; $\mathrm{MgO}(56 \% \mathrm{Mg}), 8.0 ; \mathrm{NaCl}, 6.4$; vitamin ADE premix (Cargill Animal Nutrition, Cargill Inc.), 0.48; limestone, 37.2; selenium premix (Cargill Animal Nutrition, Cargill Inc.), 0.07; and dry corn distillers grains with solubles, 46.7. Ca, 14.1\%; P, 0.39\%; Mg, 4.59\%; K, 0.44\%; S, 0.39\%; Se, $6.91 \mathrm{mg} / \mathrm{kg} ; \mathrm{Cu}, 362$ $\mathrm{mg} / \mathrm{kg} ; \mathrm{Zn}, 1,085 \mathrm{mg} / \mathrm{kg} ; \mathrm{Fe}, 186 \mathrm{mg} / \mathrm{kg}$, vitamin A, 276,717 IU/kg; vitamin D, 75,000 IU/kg; and vitamin E, $1,983 \mathrm{IU} / \mathrm{kg}$.

${ }^{11}$ Values calculated using the chemical analysis (Cumberland Valley Analytical Services Inc., Maugansville, $\mathrm{MD}$ ) of individual feed ingredients of the diet.

${ }^{12} \mathrm{CP}$ content of the DMPUM and DMPUMH diets was 15.9 and $16.0 \%$, respectively.

${ }^{13}$ Estimated based on NRC (2001).

\section{RNA Extraction and Quantitative Real-Time Reverse Transcription PCR}

Total RNA was extracted using tri-reagent (Molecular Research Center, Inc., Cincinnati, $\mathrm{OH}$ ) and
RNeasy mini kit (Qiagen, Valencia, CA) following the manufacturers' protocols. Muscle was homogenized in tri-reagent followed by chloroform extraction according to the manufacturer's instruction. An equal volume of $70 \%$ ethanol was added to the aqueous phase and the 
mixture was loaded on a Qiagen mini spin column. The Qiagen mini kit protocol was followed from this step onwards including the on-column DNase I treatment to remove residual DNA contamination. The RNA was eluted from the column with RNase-free water and an aliquot was used for quantitation (NanoDrop 2000, Thermo Fisher Scientific, Waltham, MA). Quality of the RNA was analyzed on a $1 \%$ agarose gel. Total RNA $(1 \mu \mathrm{g})$ was reversed transcribed using superscript III reverse transcriptase (Invitrogen, Carlsbad, CA) following manufacturer's instruction.

Quantification of the mRNA of the candidate genes was performed by using real-time reverse transcription PCR in an Mx3000P cycler (Stratagene, Amsterdam, the Netherlands, and Agilent, Santa Clara, CA) and in accordance with MIQE guidelines (Bustin et al., 2009). Different genes were measured on different plates (i.e., sample maximization method). The temperature profile of real-time PCR and primer characteristics are shown in Table 2. The reaction was performed in triplicate in a total volume of $10 \mu \mathrm{L}$ consisting of $2 \mu \mathrm{L}$ of cDNA (diluted 1:4) as template, $1 \mu \mathrm{L}$ of primer mix, $2 \mu \mathrm{L}$ of water, and $5 \mu \mathrm{L}$ of the SYBR Green JumpStart Taq Readymix (Sigma-Aldrich, Steinheim, Germany). Each PCR run contained a negative template control for quantitative PCR. For each PCR reaction, a standard curve was generated using serial dilution of cDNA to calculate efficiency-corrected relative quantities of the targets (run-specific target amplification efficiency). The investigated transcripts had real-time PCR efficiency rates ranging from 1.89 to 2.06 . A set of 2 inter-run calibrators were used on each plate to correct the inter-run variation.

To determine the most stably expressed genes for quantitative real-time PCR data normalization, a set of 5 genes (Saremi et al., 2012) was tested and their stability was evaluated using qBASE ${ }^{\text {plus }}$ version 2.0 (Biogazelle, Ghent, Belgium). Average expression stability $(\mathrm{M})$ and pairwise variation $(\mathrm{V})$ values for determination of the stable reference genes and the optimal number of reference genes were calculated using geNormplus as a part of $\mathrm{qBASE}^{\text {plus }}$. Four reference genes, namely low-density lipoprotein receptor-related protein 10 (LRP10), marvel domain containing 1 (MARVELD), RNA polymerase II (POLR2A), and emerin (EMD) were determined as the most stable reference genes. The reference genes selected and used in the current study, had $\mathrm{M}$ and $\mathrm{V}$ values below the threshold levels of 1.5 and 0.15 , respectively (Vandesompele et al., 2002). The software was also used for all subsequent calculations and data quality controls (Hellemans et al., 2007). The output data from qBASE ${ }^{\text {plus }}$ were calibrated normalized relative quantities.

\section{Western Blotting}

Muscle was homogenized in 4 volumes of ice-cold homogenization buffer consisting of $20 \mathrm{mmol} / \mathrm{L}$ of HEPES (pH 7.4), $2 \mathrm{mmol} / \mathrm{L}$ of EGTA, $50 \mathrm{mmol} / \mathrm{L}$ of sodium fluoride, $100 \mathrm{mmol} / \mathrm{L}$ of potassium chloride, $0.2 \mathrm{mmol} / \mathrm{L}$ of EDTA, $50 \mathrm{mmol} / \mathrm{L}$ of $\beta$-glycerol phosphate, $1 \mathrm{mmol} / \mathrm{L}$ of dithiothreitol (DTT), $0.1 \mathrm{mmol} / \mathrm{L}$ of phenylmethylsulfonyl fluoride, $1 \mathrm{mmol} / \mathrm{L}$ of benzamidine, and $0.5 \mathrm{mmol} / \mathrm{L}$ of sodium vanadate using a Polytron homogenizer (Kinematic Polytron, Brinkman, Westbury, NY) and clarified by centrifugation $\left(10,000 \times g, 10 \mathrm{~min}, 4^{\circ} \mathrm{C}\right.$; Lang et al., 2013). Protein concentration was quantified using BioRad Protein Assay Dye reagent concentrate (BioRad, Hercules, CA) and SDS-PAGE was performed using equal amounts of total protein per sample and gels containing different percentages of polyacrylamide (percentage noted below) made in laboratory. Following Ponceau S (Aqua Solutions, Deer Park, TX) staining to verify loading of equal amounts of protein, polyvinylidene fluoride membranes were blocked in 5\% nonfat dry milk and then incubated overnight a $4^{\circ} \mathrm{C}$ with primary antibody to determine the total and phospho-specific isoforms of the protein of interest. Unless otherwise noted, primary antibodies were purchased from Cell Signaling (Beverly, MA). Specifically, Western analysis was performed for total and Ser2448-phosphorylated mTOR (6\% gel; 1:1,000 dilution, catalog \#2972 and \#2971, respectively); total (12\% gel; 1:10000 dilution, catalog \#SC-230, Santa Cruz Biotechnology, Santa Cruz, CA) and Thr389-phosphorylated (10\% gel; 1:1,000 dilution, catalog \#9205); total and Ser240/244-phosphorylated ribosomal protein S6 (10\% gel; 1:10,000 and 1:5,000 dilution, respectively; catalog \#2217 and \#2215); total (15\% gel; 1:1000 dilution; catalog \#9456) and Ser65phosphorylated (15\% gel; 1:8,000 dilution; catalog \#9452) eukaryotic initial factor 4E binding protein-1 (4E-BP1), and total and Ser473-phosphorylated protein kinase B (Akt; $10 \%$ gel; 1:5,000 dilution; catalog \#9272 and \#9271, respectively). The secondary antibody was goat anti-rabbit IgG (Sigma-Aldrich, St. Louis, MO; catalog \#A4914) and was added in 5\% nonfat milk for $1 \mathrm{~h}$ before washing. Blots were developed with enhanced chemiluminescence Western blotting reagents and then exposed to x-ray film in a cassette equipped with a DuPont Lightning Plus intensifying screen. The film was scanned (ScanMaker IV; Microtek, Cerritos, $\mathrm{CA}$ ) and band density was analyzed in the linear range using National Institutes of Health Image 1.6 software (National Institutes of Health, Bethesda, MD). Western analysis was performed on muscle samples from all animals ( $\mathrm{n}=9$ per group). Specifically, each gel contained 
Table 2. Characteristics of primers and real-time polymerase chain reaction conditions

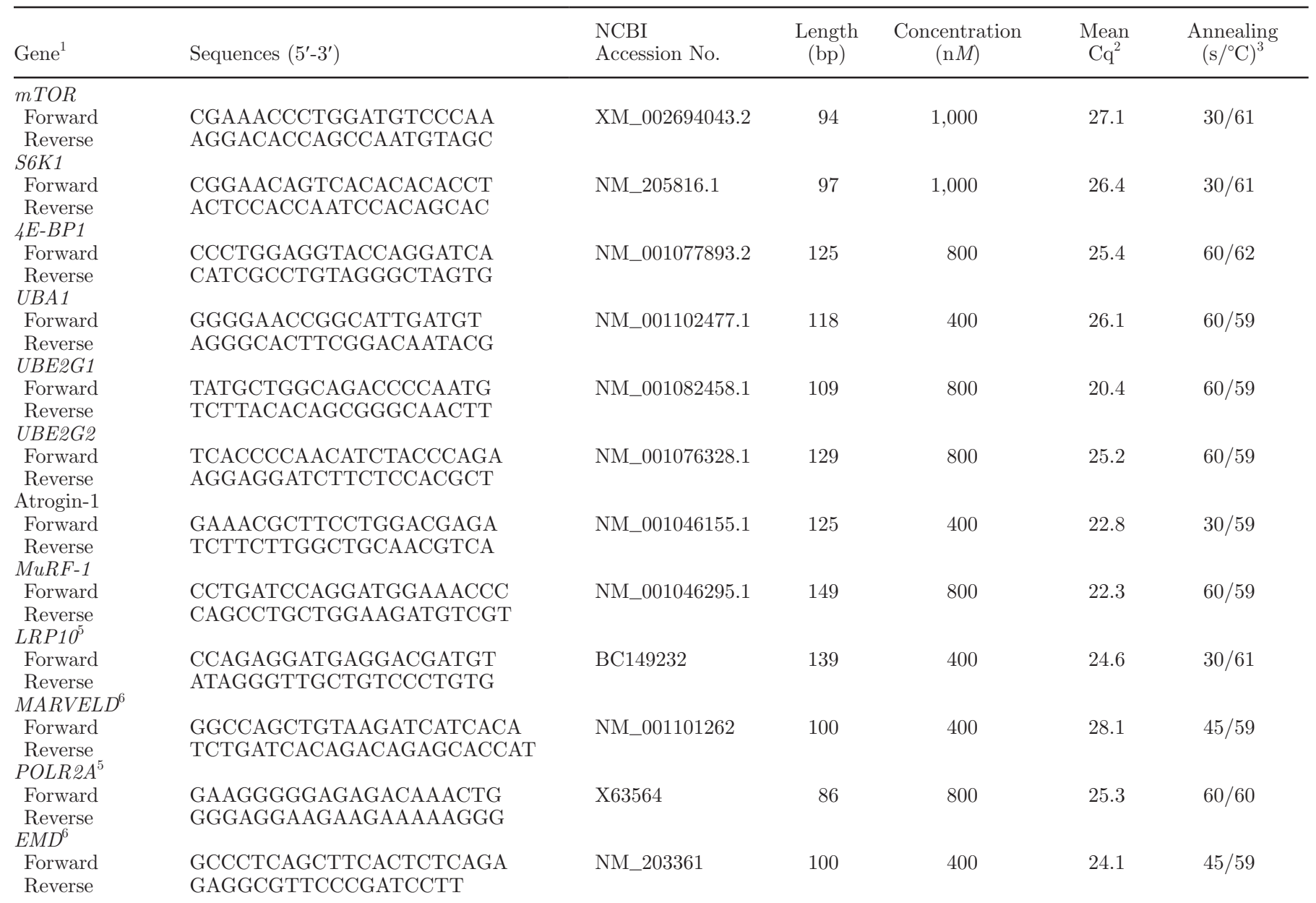

${ }^{1} m T O R=$ mammalian target of rapamycin; $S 6 K 1=$ ribosomal protein S6 kinase, polypeptide 1; 4E-BP1= eukaryotic translation initiation factor $4 \mathrm{E}$ binding protein $1 ; U B A 1=$ ubiquitin-like modifier activating enzyme 1; UBE2G1 = ubiquitin-conjugating enzyme E2G 1; UBE2G2 $=$ ubiquitin-conjugating enzyme E2G $2 ; M u R F-1=$ muscle ring-finger protein-1; LRP10 = lipoprotein receptor-related protein 10; $M A R V E L D$ $=$ Marvel domain containing $1 ;$ POLR2A $=$ RNA polymerase II; EMD = Emerin

${ }^{2}$ Mean quantification cycle.

${ }^{3}$ Initial denaturation for $10 \mathrm{~min}$ at $90^{\circ} \mathrm{C}$; denaturation for $30 \mathrm{~s}$ at $95^{\circ} \mathrm{C}$; extension for $30 \mathrm{~s}$ at $72^{\circ} \mathrm{C}$, except for $4 E-B P, U B A 1, U B E 2 G 1, U B E 2 G 2$, $M u R F-1\left(60 \mathrm{~s}\right.$ at $\left.72^{\circ} \mathrm{C}\right)$, and $\operatorname{LRP} 10\left(20 \mathrm{~s}\right.$ at $\left.72^{\circ} \mathrm{C}\right)$.

${ }^{5}$ Hosseini et al. (2010).

${ }^{6}$ Saremi et al. (2012).

3 independent samples from each treatment group, plus 2 lanes of a pooled control sample run on each gel. As we observed no difference as to whether data were normalized to the AMP or pooled control group (data not shown), we then normalized to the AMP group on the same gel because of lower variability of data. Hence, the AMP samples on each gel were used as the control group, the mean for this group set at $100 \%$, and the resulting data were presented as a percentage and values are expressed as means \pm standard error of the mean. Muscle biopsies were stored at $-80^{\circ} \mathrm{C}$ for 1 mo, whereby all samples were stored frozen for approximately the same duration; samples were homogenized and Western blots performed at the same time.

\section{Blood Sampling and Analysis}

Blood samples were collected from the coccygeal vein or artery using heparinized Vacutainer tubes (Becton Dickinson, Franklin Lakes, NJ) on at 6, 10, and $14 \mathrm{~h}$ after the morning feeding d 3 of wk 2 of the covariate period and wk 6 and 8 of the experimental period. Blood samples were immediately centrifuged at 1,500 $\times g$ for 15 min at $4^{\circ} \mathrm{C}$. The plasma was recovered and frozen $\left(-20^{\circ} \mathrm{C}\right)$ until analysis. Plasma samples were composited on an equal-volume basis per cow and sampling week and analyzed for BHB on the Cobas Mira Plus Chemistry Analyzer (F. Hoffmann-La Roche Ltd., Basel, Switzerland) using a commercial kit (Ranbut, 
Table 3. Effects of slow-release urea and rumen-protected (RP) AA supplementation on the mRNA abundance (LSM \pm SEM) of genes related to mammalian target of rapamycin (mTOR) and ubiquitin-proteasome system (UPS) in skeletal muscle of dairy cows

\begin{tabular}{|c|c|c|c|c|c|c|c|c|c|c|}
\hline \multirow[b]{2}{*}{ Item $^{1}$} & \multicolumn{5}{|c|}{ Diet $^{2}$} & \multirow[b]{2}{*}{ SEM } & \multicolumn{4}{|c|}{ Contrasts $^{3}$} \\
\hline & AMP & DMP & DMPU & DMPUM & DMPUMH & & MP & $\mathrm{U}$ & Met & His \\
\hline \multicolumn{11}{|l|}{ mTOR } \\
\hline$m T O R$ & 1.23 & 1.12 & 1.11 & 1.19 & 1.20 & 0.08 & 0.32 & 0.99 & 0.49 & 0.91 \\
\hline S6K1 & 1.17 & 1.03 & 1.07 & 1.04 & 0.95 & 0.11 & 0.39 & 0.85 & 0.88 & 0.50 \\
\hline $4 E-B P 1$ & 1.01 & 1.04 & 1.04 & 1.10 & 0.83 & 0.24 & 0.92 & 0.99 & 0.84 & 0.38 \\
\hline \multicolumn{11}{|l|}{ UPS } \\
\hline UBE2G2 & 1.25 & 1.12 & 1.24 & 1.20 & 1.13 & 0.13 & 0.50 & 0.53 & 0.83 & 0.69 \\
\hline Atrogin-1 & 1.07 & 1.25 & 1.01 & 0.72 & 0.88 & 0.14 & 0.35 & 0.20 & 0.13 & 0.40 \\
\hline$M u R F-1$ & 1.16 & 1.59 & 0.89 & 0.73 & 0.91 & 0.25 & 0.21 & 0.04 & 0.63 & 0.58 \\
\hline
\end{tabular}

${ }^{1} S 6 K 1=$ ribosomal protein S6 kinase, polypeptide 1; $4 E-B P 1=$ eukaryotic translation initiation factor 4E binding protein; $U P S=$ ubiquitinproteasome system; $U B A 1=$ ubiquitin-like modifier activating enzyme 1; UBE2G1 and UBE2G2= ubiquitin-conjugating enzymes; $M u R F-1=$ muscle ring-finger protein-1.

${ }^{2} \mathrm{AMP}=\mathrm{MP}$-adequate diet; DMP = MP-deficient diet; DMPU = DMP diet supplemented with Optigen (Alltech Inc., Nicholasville, KY); DMPUM = DMPU diet supplemented with RPMet (Mepron; Evonik Industries AG, Hanau, Germany); DMPUMH = DMPUM diet supplemented with RPHis (Balchem Corp., New Hampton, NY).

${ }^{3} \mathrm{MP}=\mathrm{DMP}$ vs. AMP; U = DMPU vs. DMP; Met = DMPUM vs. DMPU; and His = DMPUMH vs. DMPUM.

RB 1008; Randox Laboratories GmbH, Wülfrath, Germany).

\section{Statistical Analyses}

The final results were calculated by $\mathrm{qBASE}^{\text {plus }}$ (i.e., the calibrated normalized relative quantities values were used for statistical analysis of the mRNA data). Statistical analysis was performed using SAS software (SAS Institute, 2012). The data were analyzed using a Generalized Linear Mixed Model (GLMM) approach using the SAS procedure GLIMMIX (Stroup, 2012). The same model was used for all data and included phase, treatment, and interaction of treatment $\times$ phase as the fixed effects and block as the random effect. Preplanned single degree of freedom contrasts were used for mean comparisons as follows: $\mathrm{MP}=\mathrm{DMP}$ versus AMP; $\mathrm{U}=\mathrm{DMPU}$ versus DMP; Met $=$ DMPUM versus DMPU; and His = DMPUMH versus DMPUM. The threshold of significance was set at $P<0.05$; trends were declared at $0.05<P<0.10$.

\section{RESULTS}

\section{mRNA Abundance of Genes in the Skeletal Muscle}

As shown in the Table 3, the mRNA abundance of genes related to the mTOR signaling pathway, including $m T O R$, S6K1, and $4 E-B P 1$, was not affected by treatment. The mRNA abundance of ubiquitin activating (UBA1) and conjugating (UBE2G1, UBE2G2) enzymes and atrogin-1 also did not differ among treatment groups (Table 3). The abundance of $M u R F-1$
mRNA was 1.79 -fold greater $(P=0.04$; Table 3$)$ in DMP than in DMPU cows.

\section{Protein Abundance and Phosphorylation of the mTOR Signaling Pathway}

As presented in Figure 1, the abundance of phosphorylated $(\mathbf{P})$-mTOR tended to be greater $(P=0.07)$ in DMP than in AMP. The P-mTOR values in DMPU were decreased $(P<0.01)$ when compared against DMP. In addition, the P-mTOR values were lower $(P=$ 0.01) in DMPUMH than in DMPUM. The abundance of total ( $\mathbf{T})-\mathrm{mTOR}$ was not affected by treatment. The abundance of T- and P-S6K1 also did not differ among treatments (Figure 1). Conversely, we noted no statistically significant differences among the 5 groups for Ser65-phosphorylated 4E-BP1 $(100 \pm 11,98 \pm 13,111$ $\pm 12,95 \pm 11$, and $108 \pm 9 \%$, respectively) or the total amount of 4E-BP1 (data not shown) in muscle.

The P-S6 values in DMPUM tended to increase when compared against DMPU $(P=0.09$; Figure 2$)$. The abundance of T-S6 in DMP was increased $(P=0.02)$ or tended $(P=0.09)$ to be increased when compared with AMP and DMPU, respectively. No differences were observed among the treatment groups for the abundance of P- or T-Akt (Figure 2). No differences were observed among the treatment groups for the plasma concentrations of BHB (Figure 3).

\section{DISCUSSION}

Results concerning the performance variables measured with emphasis on DMI, milk and milk protein 
A

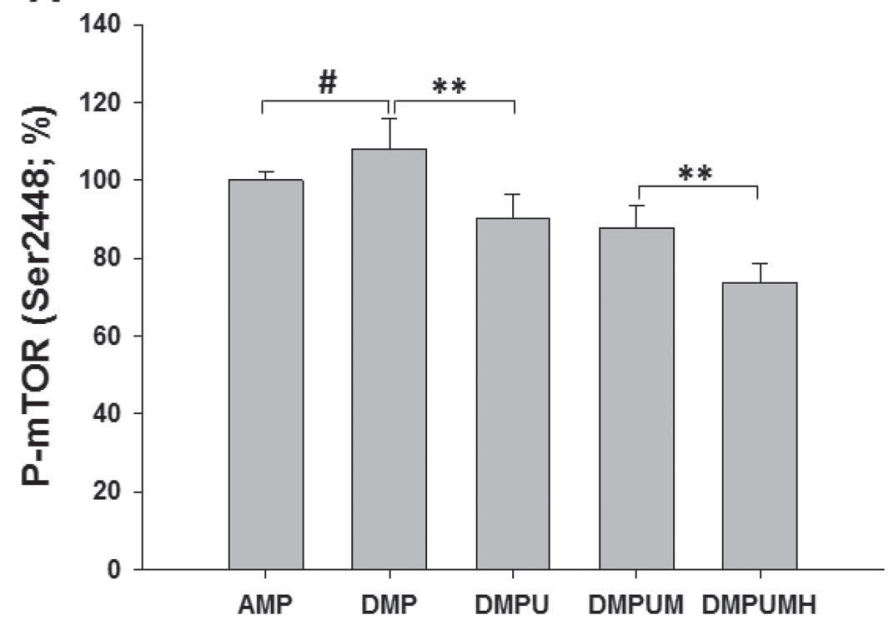

C

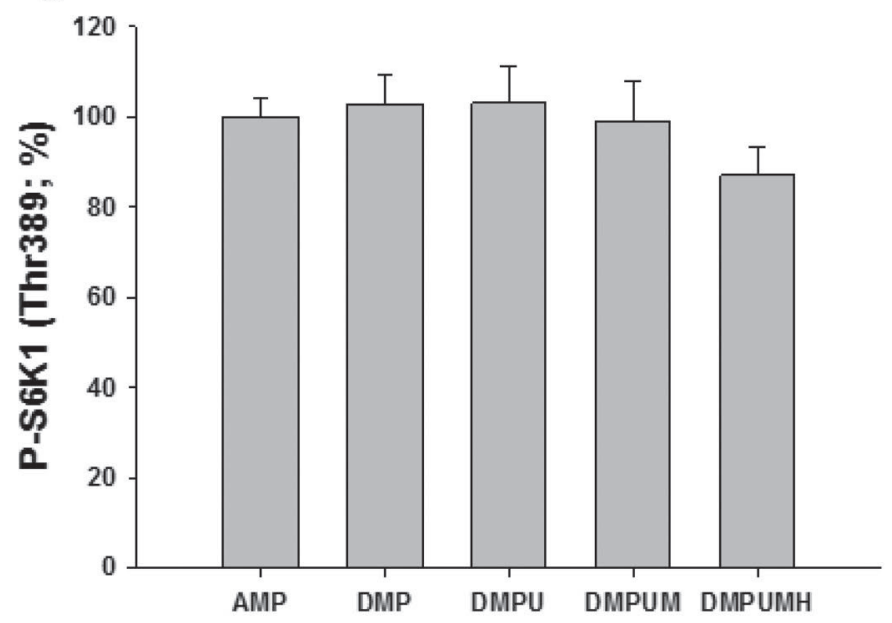

B

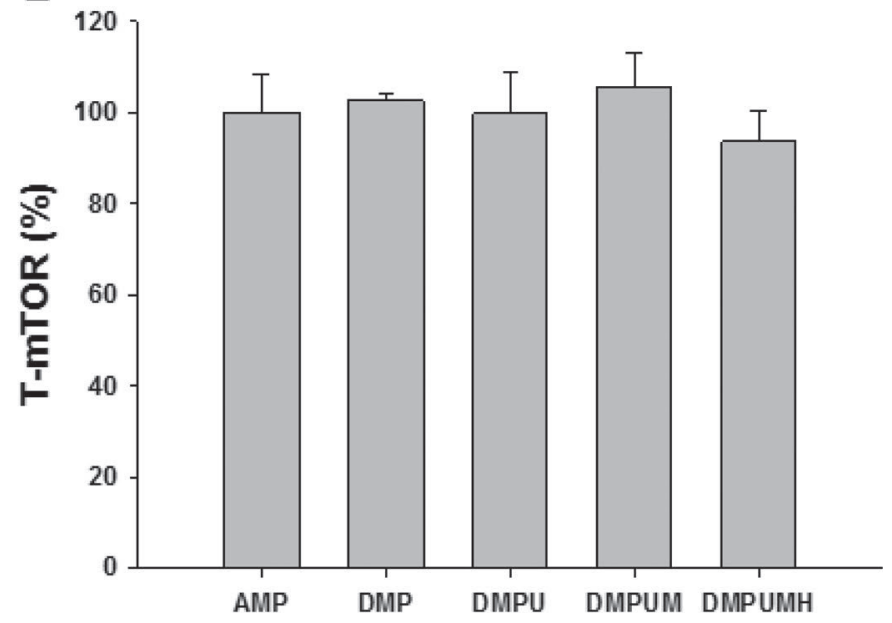

D

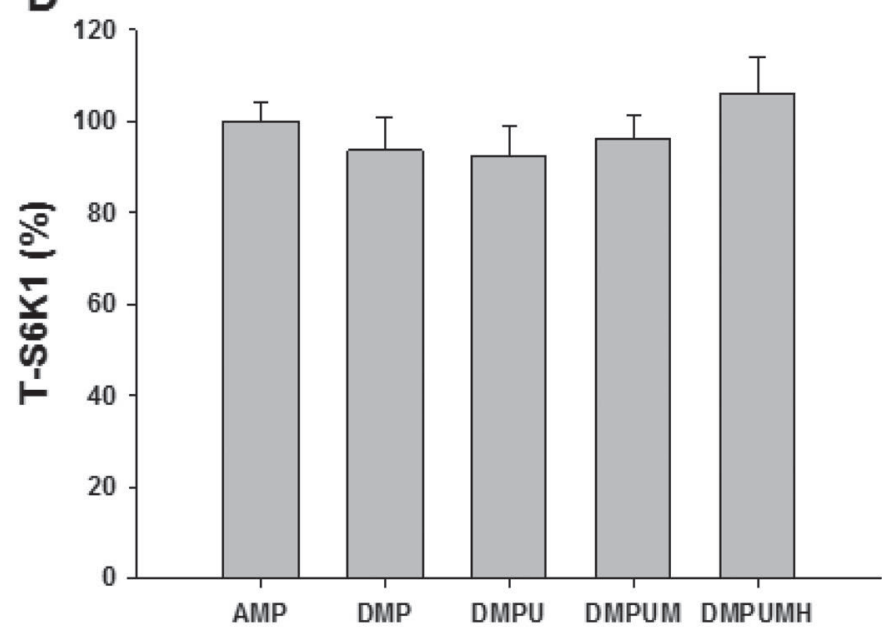

E

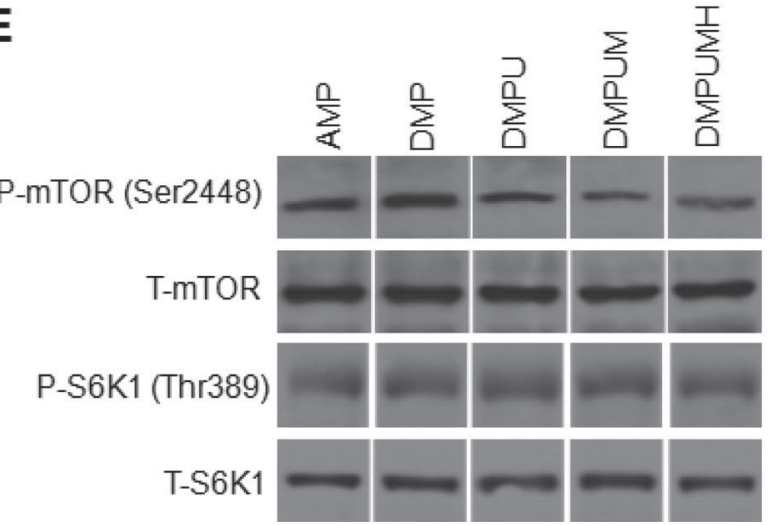

Figure 1. Effects of dietary supplementation with slow-release urea or rumen-protected AA on (A) phosphorylated (P; Ser2448)- and (B) total (T)-mammalian target of rapamycin (mTOR) as well as (C) P (Thr389)- and (D) T-ribosomal protein S6 kinase (S6K1) in skeletal muscle of dairy cows. Bar graphs quantitate the results (means \pm SEM) from immunoblot densitometry. $* * P \leq 0.01$; $\# P=0.07$. (E) Representative Western blots for P- and T-mTOR and P- and T-S6K1 in all treatment groups. For each protein, samples from all experimental groups were run on the same gel; white lines between samples on blots indicate intervening lanes have been spliced. $\mathrm{AMP}=\mathrm{MP}$-adequate diet; $\mathrm{DMP}=$ MP-deficient diet; DMPU = DMP diet supplemented with slow-release urea; DMPUM = DMP diet supplemented with slow-release urea and rumen-protected (RP) Met; DMPUMH = DMP diet supplemented with slow-release urea, RPMet, and RPHis. 

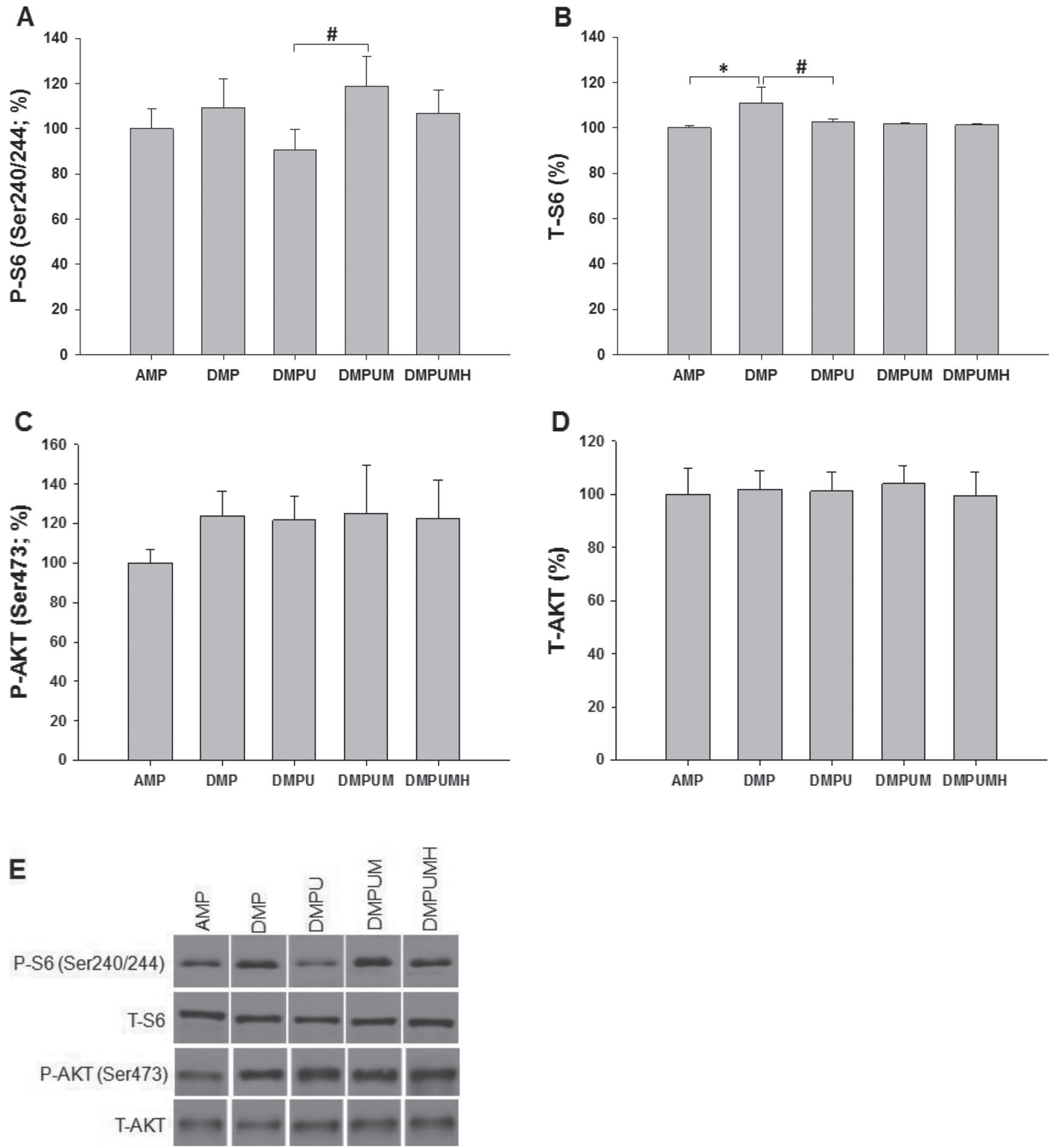

Figure 2. Effects of dietary supplementation with slow-release urea or rumen-protected AA on (A) phosphorylated (P; Ser240/244)- and (B) total (T)-ribosomal protein S6 (S6) as well as (C) P (Ser473)- and (D) T-protein kinase B (Akt) in skeletal muscle of dairy cows. Bar graphs quantitate the results (means $\pm \mathrm{SEM}$ ) from immunoblot densitometry; ${ }^{*} P=0.02$; $\# P=0.09$. (E) Representative Western blots for T- and $\mathrm{P}$-S6 and T- and P-Akt in all treatment groups. For each protein, samples from all experimental groups were run on the same gel; white lines between samples on blots indicate intervening lanes have been spliced. AMP $=$ MP-adequate diet; DMP $=$ MP-deficient diet; DMPU $=$ DMP diet supplemented with slow-release urea; DMPUM = DMP diet supplemented with slow-release urea and rumen-protected (RP) Met; DMPUMH = DMP diet supplemented with slow-release urea, RPMet, and RPHis. 


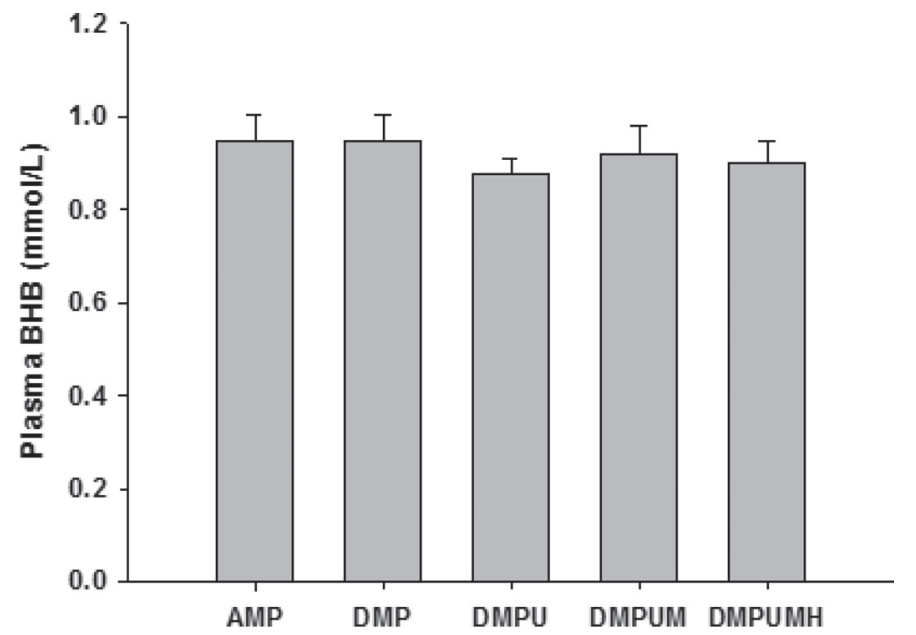

Figure 3. Effects of dietary supplementation with slow-release urea or rumen-protected AA on plasma concentrations of BHB (means \pm SEM) in dairy cows. Main effect of treatment, $P=0.68$. AMP $=$ MPadequate diet; $\mathrm{DMP}=\mathrm{MP}$-deficient diet; $\mathrm{DMPU}=\mathrm{DMP}$ diet supplemented with slow-release urea; DMPUM $=$ DMP diet supplemented with slow-release urea and rumen-protected (RP) Met; DMPUMH $=$ DMP diet supplemented with slow-release urea, RPMet, and RPHis.

yields, plasma and muscle AA concentrations, and $\mathrm{N}$ excretion from the present animal experiment were published previously (Giallongo et al., 2015) and demonstrated that cows receiving 5\% MP-deficient diet (according to NRC, 2001) had elevated plasma concentrations of 3-MH and gained less BW compared with the control and cows fed the slow-release ureasupplemented diet. Herein, we sought to determine whether supplementation of a MP-deficient diet with slow-release urea and RPMet and RPHis would affect the abundance of specific signaling components in the skeletal muscle that support protein synthesis and decrease proteolysis.

In the current study, the mRNA abundance of $M u R F-1$ was 1.79 -fold greater in DMP as compared with DMPU. These findings may indicate upregulation of the UPS system at the mRNA level, which is consistent with the plasma 3-MH data. The UPS is regarded as the main proteolytic pathway in muscle. It requires the coordinated reactions of 3 enzymes including ubiquitin-activating enzyme (E1), ubiquitin-conjugating enzyme (E2), and ubiquitin ligases (E3; Schulman and Harper, 2009; David et al., 2010). The targeted proteins for degradation by the UPS are first tagged in the ubiquitination pathway (Nandi et al., 2006) and are later proteolyzed by the proteasome enzyme complex. The E3 ligases including MuRF-1 and atrogin-1 are specific markers of muscle wasting and their abundance is crucial for skeletal muscle degradation in catabolic state (Bodine et al., 2001; Gomes et al., 2001; Foletta et al., 2011). Taken together, feeding an MP-deficient diet (according to NRC, 2001) was effective to enhance the expression of $M u R F-1$ and, as a consequence, proteolysis might have been stimulated.

The mTOR complex has a central role in regulating cell growth and metabolism in eukaryotes (Wullschleger et al., 2006) and its signaling pathway is mediated by 2 functionally distinct multiprotein complexes, mTORC1 and mTORC2 (Sarbassov et al., 2005; Inoki and Guan, 2006; Yang et al., 2008). The mTORC1 is a nutrient and energy sensor, in particular of AA (Hay and Sonenberg, 2004). Ribosomal protein S6 kinase and 4E-BP1 are the 2 best-characterized substrates of mTORC1. The mTORC1 phosphorylates 4E-BP1 which then releases eukaryotic translation initiation factor (eIF) $4 \mathrm{E}$, allowing assembly of the eIF4F complex. Phosphorylation of S6K1 by mTORC1 promotes protein synthesis and cell growth by phosphorylating multiple substrates including S6 and translational regulator eIF4B (Hay and Sonenberg, 2004). Phosphorylation of S6 by S6K1 promotes transcription of genes that may enhance ribosome biogenesis (Chauvin et al., 2014). In the present study, P-mTOR and T-S6 values in the DMP group were and tended to be increased when compared against the AMP and the DMPU group, respectively. The mTOR senses nutrient availability, and is thus activated under nutrient-rich conditions, particularly high levels of AA. Nutrient restriction $\left(68.1 \%\right.$ of $\mathrm{NE}_{\mathrm{M}}$ and $86.7 \%$ of MP requirement) in Angus-Gelbvieh crossbred cows did not affect the content of mTOR and S6, whereas the phosphorylation of mTOR (Ser2448) and S6 (Ser235/336) was lower in muscle tissue from nutrient-restricted cows than from control animals, indicating that nutrient restriction inhibited protein synthesis in muscle tissue (Du et al., 2005). The mechanism of the upregulation of P-mTOR in cows fed the DMP diet, despite greater $M u R F-1$ mRNA abundance and plasma 3-MH remains to be clarified; although it might be related to a higher rate of protein turnover in muscle tissue of these cows. Two proteolytic systems are mainly responsible for the turnover of proteins and organelles: the proteasome (UPS) and the lysosomal system, both working in tandem (Ciechanover, 2005). When UPS is stimulated (as evidenced by the increase of $M u R F-1$ mRNA abundance in this study), the proteolytic system, regulated by lysosomal degradation is also increased. Thus, an increase in P-mTOR (Ser2448) is likely due to its activation at the surface of the lysosome by the RAG-regulator complexes in response to increased autophagy, and stimulated uptake, or release of lysosomal AA (Sancak et al., 2010; Narita and Inoki, 2012). As reported previously from this animal experiment, excretion of urinary urea- $\mathrm{N}$ as a percent of total urinary $\mathrm{N}$ was lowered in DMP cows when compared with AMP and DMPU cows $(47,58$, and $64 \%$, respec- 
tively; Giallongo et al., 2015). The mechanism by which urinary urea-N excretion was reduced by the DMP was likely, at least in part, due to increased reutilization of $\mathrm{AA}$, an important factor contributing to the economy of protein metabolism, and thus to decreased catabolic clearance of AA. In this regard, the intramuscular concentrations of Gln in the DMP, which have been positively associated with muscle protein synthesis (Millward et al., 1989; Wu et al., 2011), were comparable with other treatment groups (Giallongo et al., 2015). Thus, the reduction in the plasma concentrations of branched-chain AA, Ile and Val, in cows fed the DMP diet in this experiment (as reported in Giallongo et al., 2015) is likely due to increased cellular uptake by skeletal muscle to compensate for the decline in plasma Ile and Val concentrations and to maintain intracellular concentrations, assuming that a single time point measurement in the current study is representative of the steady-state levels of these AA. In support of this, Churchward-Venne et al. (2014) recently reported that the intracellular levels of the branched-chain AA remained unchanged despite a decline in plasma levels, suggesting that the decrease in plasma AA concentrations likely results from increased AA uptake to maintain the intracellular concentrations (Columbus et al., 2015).

As reported previously from this experiment, addition of RPHis increased milk protein concentration and yield and numerically increased BW gain (Giallongo et al., 2015). Therefore, reduced abundance of P-mTOR in DMPUMH as compared with DMPUM may suggest that His was partitioned in favor of milk protein, rather than muscle protein synthesis, and that the numerically higher BW gain likely resulted from body fat gain. The reason for the lower abundance of P-mTOR with the DMPUMH diet is not known. Deficiency of all EAA or depletion of Leu and Ile reduced mTOR phosphorylation in bovine mammary tissue slices (Appuhamy et al., 2012). However, in the current study, none of the EAA analyzed in the muscle was affected by supplementation of RPHis (Giallongo et al., 2015). Nevertheless, muscle concentration of Glu was decreased and those of Asp tended to be decreased with DMPUMH compared with DMPUM (Giallongo et al., 2015). We thus speculated that the lower abundance of P-mTOR by the DMPUMH diet was likely, at least in part, affected by the lower concentrations of the nonessential AA, Glu and Asp, in the muscle; however, this warrants further investigation. In the current study, the muscle biopsy was sampled only from the longissimus dorsi, and we also did not determine muscle fiber type composition in the samples. Skeletal muscle, a complex multicellular tissue, is composed of a set of fiber types differing in their functional and metabolic pro- files (Gunawan et al., 2007); consequently, each fiber type may contribute differently in response to the diet or treatment. Studies in neonatal pigs suggested that in skeletal muscle, the increase in protein synthesis in response to anabolic signals is fiber type dependent; the response in longissimus dorsi, a muscle composed of primarily fast-twitch glycolytic fibers (type IIb), is more profound as compared with muscles composed of mixed glycolytic and oxidative fibers (type IIa) or slowtwitch oxidative fibers (type I; Gazzaneo et al., 2011; Columbus et al., 2015). The response of muscles with different fiber types to feeding an MP-deficient diet or slow-release urea and RP AA-supplemented diets has yet to be determined. It is also likely that the increased milk protein concentration in response to addition of RPHis was associated with altered mTOR signaling in the mammary gland; thus, the mTOR results might have been different if mammary tissue would have been investigated.

The activation of protein synthesis by insulin is mediated primarily through the insulin receptor/insulin receptor substrate 1/phosphatidylinositol-3-kinase/Akt pathway. The Akt phosphorylates and inactivates tuberous sclerosis complex 2, leading to increased mTOR activity (Proud, 2006; Davis et al., 2010). Appuhamy et al. (2011) reported that, regardless of EAA availability, addition of insulin to MAC-T cells increased phosphorylation of Akt and mTOR and its downstream targets, S6K1 and 4EBP1. In the current study, neither P-Akt nor T-Akt was affected by the treatments. As reported previously in this experiment, plasma insulin concentrations were not affected by treatments, except a numerical increase in the DMP animals when compared with the AMP group (Giallongo et al., 2015). The reason for this observation is not clear. However, this may explain, at least in part, the reason for the observed upregulation of P-mTOR and T-S6 by the DMP diet compared with AMP. Interestingly, the response to insulin in terms of protein synthesis in neonatal pigs is specific for skeletal muscle, as protein synthesis in visceral tissues does not respond to insulin infusion (Davis et al., 2001; Suryawan et al., 2009). To our knowledge, it is currently unknown whether insulin acts in the same manner in dairy cows. As reported previously, cows fed the MP-adequate diet and cows on the supplemented diets (i.e., slow-release urea and RP AA) were regaining BW lost in early lactation (Giallongo et al., 2015), probably due to body fat gain and increased muscular protein synthesis, as milk protein yield was not affected by the MP levels. We did not evaluate the effects of diets on tissue-specific or wholebody protein synthesis; it thus remains to be elucidated to what extent the observed BW gain in the groups receiving the supplemented diets, provided it is not 
only body fat, might be supported by increased protein synthesis in visceral tissues or in skeletal muscles other than longissimus dorsi.

van der Drift et al. (2012) reported that higher plasma 3-MH concentrations were associated with lower circulating concentrations of BHB in dairy cows during the periparturient period. They hypothesized that greater muscle breakdown, at least in part, might have restricted ketone body production through providing AA for gluconeogenesis in early-lactation dairy cows. In humans, proteolysis of muscle results in the release of AA into the circulation, predominantly Ala and Gln, which are involved in transferring both amino groups and carbon atoms for urea synthesis and gluconeogenesis, respectively, in the liver (Frayn, 2010). However, in a review of recently available quantitative data on hepatic metabolism of glucose, AA and other glucogenic precursors in the periparturient period, Larsen and Kristensen (2013) concluded that only Ala is likely to contribute to liver release of glucose through its role in the interorgan transfer of $\mathrm{N}$ from catabolized AA. In the current study, the circulating concentrations of BHB were within the range typically observed in dairy cows without any difference among groups. Interestingly, as reported previously from this experiment, circulating glucose concentrations were numerically $(P$ $=0.12$ ) greater in the DMP than in the AMP group (Giallongo et al., 2015). However, neither plasma nor muscle Ala concentrations were changed between DMP and AMP groups.

\section{CONCLUSIONS}

Feeding the 5\% MP-deficient diet increased the mRNA abundance of $M u R F-1$, which may be related to upregulation of the UPS and, consequently, stimulation of protein degradation in the muscle tissue. The observed upregulation of P-mTOR and T-S6 in cows fed the DMP diet, in spite of the increase in $M u R F-1$ mRNA abundance and plasma $3-\mathrm{MH}$, was possibly related to a higher rate of protein turnover in the muscle that warrants further investigation. The trends for increased milk and milk protein yield by DMPUMH as compared with DMPUM coincided with the lower abundance of phosphorylated mTOR. Thus, this may indicate that RPHis was partitioned to the mammary gland for milk protein synthesis rather than to muscle protein synthesis.

\section{ACKNOWLEDGMENTS}

This study was partially supported by funds from a USDA (Washington, DC) Special Research Grants Program: Improved Dairy Management Practices, Evonik
Nutrition \& Care GmbH (Hanau, Germany), and Alltech Inc. (Nicholasville, KY). The authors thank Evonik Nutrition \& Care GmbH for providing Mepron and for AA analyses of the feed samples, Alltech Inc. for providing Optigen, Balchem Corp. (New Hampton, NY) for providing RPHis, West Central Cooperative (Ralston, IA) for providing SoyPLUS for the trial, and the staff of the Department of Animal Science Dairy Center (The Pennsylvania State University, University Park) for their conscientious care of the experimental cows. The authors also express their appreciation to Inga Hofs (Institute of Animal Science, Physiology and Hygiene Unit, University of Bonn) and Anne Pruznak (Department of Cellular and Molecular Physiology, Penn State College of Medicine, Hershey, PA; NIH GM 38032) for their excellent laboratory assistance.

\section{REFERENCES}

Aguerre, M. J., M. A. Wattiaux, T. Hunt, and B. R. Larget. 2010. Effect of dietary crude protein on ammonia-N emission measured by herd nitrogen mass balance in a freestall dairy barn managed under farm-like conditions. Animal 4:1390-1400.

Appuhamy, J. A., A. L. Bell, W. A. Nayananjalie, J. Escobar, and M. D. Hanigan. 2011. Essential amino acids regulate both initiation and elongation of mRNA translation independent of insulin in MAC-T cells and bovine mammary tissue slices. J. Nutr. 141:1209-1215.

Appuhamy, J. A., N. A. Knoebel, W. A. Nayananjalie, J. Escobar, and M. D. Hanigan. 2012. Isoleucine and leucine independently regulate mTOR signaling and protein synthesis in MAC-T cells and bovine mammary tissue slices. J. Nutr. 142:484-491.

Bodine, S. C., E. Latres, S. Baumhueter, V. K. Lai, L. Nunez, B. A. Clarke, W. T. Poueymirou, F. J. Panaro, E. Na, K. Dharmarajan, Z. Q. Pan, D. M. Valenzuela, T. M. DeChiara, T. N. Stitt, G. D. Yancopoulos, and D. J. Glass. 2001. Identification of ubiquitin ligases required for skeletal muscle atrophy. Science 294:1704-1708.

Bustin, S. A., V. Benes, J. A. Garson, J. Hellemans, J. Huggett, M. Kubista, R. Mueller, T. Nolan, M. W. Pfaffl, G. L. Shipley, J. Vandesompele, and C. T. Wittwer. 2009. The MIQE guidelinesMinimum information for publication of quantitative real-time PCR experiments. Clin. Chem. 55:611-622.

Chauvin, C., V. Koka, A. Nouschi, V. Mieulet, C. Hoareau-Aveilla, A. Dreazen, N. Cagnard, W. Carpentier, T. Kiss, O. Meyuhas, and M. Pende. 2014. Ribosomal protein S6 kinase activity controls the ribosome biogenesis transcriptional program. Oncogene 33:474-483.

Churchward-Venne, T. A., L. Breen, D. M. Di Donato, A. J. Hector, C. J. Mitchell, D. R. Moore, T. Stellingwerff, D. Breuille, E. A. Offord, S. K. Baker, and S. M. Phillips. 2014. Leucine supplementation of a low-protein mixed macronutrient beverage enhances myofibrillar protein synthesis in young men: A double-blind, randomized trial. Am. J. Clin. Nutr. 99:276-286.

Ciechanover, A. 2005. Proteolysis: From the lysosome to ubiquitin and the proteasome. Nat. Rev. Mol. Cell Biol. 6:79-87.

Columbus, D. A., J. Steinhoff-Wagner, A. Suryawan, H. V. Nguyen, A. Hernandez-Garcia, M. L. Fiorotto, and T. A. Davis. 2015. Impact of prolonged leucine supplementation on protein synthesis and lean growth in neonatal pigs. Am. J. Physiol. Endocrinol. Metab. 309:E601-E610.

David, Y., T. Ziv, A. Admon, and A. Navon. 2010. The E2 ubiquitinconjugating enzymes direct polyubiquitination to preferred lysines. J. Biol. Chem. 285:8595-8604.

Davis, T. A., M. L. Fiorotto, P. R. Beckett, D. G. Burrin, P. J. Reeds, D. Wray-Cahen, and H. V. Nguyen. 2001. Differential effects of in- 
sulin on peripheral and visceral tissue protein synthesis in neonatal pigs. Am. J. Physiol. Endocrinol. Metab. 280:E770-E779.

Davis, T. A., A. Suryawan, R. A. Orellana, M. L. Fiorotto, and D. G. Burrin. 2010. Amino acids and insulin are regulators of muscle protein synthesis in neonatal pigs. Animal 4:1790-1796.

Du, M., M. J. Zhu, W. J. Means, B. W. Hess, and S. P. Ford. 2005. Nutrient restriction differentially modulates the mammalian target of rapamycin signaling and the ubiquitin-proteasome system in skeletal muscle of cows and their fetuses. J. Anim. Sci. 83:117-123.

Foletta, V. C., L. J. White, A. E. Larsen, B. Léger, and A. P. Russell. 2011. The role and regulation of MAFbx/atrogin-1 and MuRF1 in skeletal muscle atrophy. Pflugers Arch. 461:325-335.

Frayn, K. N. 2010. Metabolic Regulation: A Human Perspective. 3rd ed. Blackwell Science, Oxford, UK.

Gazzaneo, M. C., R. A. Orellana, A. Suryawan, A. P. Tuckow, S. R. Kimball, F. A. Wilson, H. V. Nguyen, R. M. Torrazza, M. L. Fiorotto, and T. A. Davis. 2011. Differential regulation of protein synthesis and mTOR signaling in skeletal muscle and visceral tissues of neonatal pigs after a meal. Pediatr. Res. 70:253-260.

Giallongo, F., A. N. Hristov, J. Oh, T. Frederick, H. Weeks, J. Werner, H. Lapierre, R. A. Patton, A. Gehman, and C. Parys. 2015. Effects of slow-release urea and rumen-protected methionine and histidine on performance of dairy cows. J. Dairy Sci. 98:3292-3308.

Glass, D. J. 2003. Molecular mechanisms modulating muscle mass. Trends Mol. Med. 9:344-350.

Gomes, M. D., S. H. Lecker, R. T. Jagoe, A. Navon, and A. L. Goldberg. 2001. Atrogin-1, a muscle-specific F-box protein highly expressed during muscle atrophy. Proc. Natl. Acad. Sci. USA 98:14440-14445.

Gunawan, A. M., S. K. Park, J. M. Pleitner, L. Feliciano, A. L. Grant, and D. E. Gerrard. 2007. Contractile protein content reflects myosin heavy-chain isoform gene expression. J. Anim. Sci. 85:12471256.

Hay, N., and N. Sonenberg. 2004. Upstream and downstream of mTOR. Genes Dev. 18:1926-1945.

Hellemans, J., G. Mortier, A. De Paepe, F. Speleman, and J. Vandesompele. 2007. qBase relative quantification framework and software for management and automated analysis of real-time quantitative PCR data. Genome Biol. 8:R19.

Hosseini, A., H. Sauerwein, and M. Mielenz. 2010. Putative reference genes for gene expression studies in propionate and $\beta$-hydroxybutyrate treated bovine adipose tissue explants. J. Anim. Physiol. Anim. Nutr. (Berl.) 94:e178-e184.

Hristov, A. N., and F. Giallongo. 2014. Feeding protein to dairy cows - What should be our target? Pages 75-84 in Proc. Tri-State Dairy Nutrition Conf., Fort Wayne, IN. The Ohio State University, Columbus.

Hristov, A. N., M. Hanigan, A. Cole, R. Todd, T. A. McAllister, P. M. Ndegwa, and A. Rotz. 2011. Review: Ammonia emissions from dairy farms and beef feedlots: A review. Can. J. Anim. Sci. 91:1-35.

Huhtanen, P., and A. N. Hristov. 2009. A meta-analysis of the effects of dietary protein concentration and degradability on milk protein yield and milk $\mathrm{N}$ efficiency in dairy cows. J. Dairy Sci. 92:3222-3232.

Inoki, K., and K. L. Guan. 2006. Complexity of the TOR signaling network. Trends Cell Biol. 16:206-212.

Lang, C. H., A. Pruznak, M. Navaratnarajah, K. A. Rankine, G. Deiter, H. Magne, E. A. Offord, and D. Breuillé. 2013. Chronic $\alpha$-hydroxyisocaproic acid treatment improves muscle recovery after immobilization-induced atrophy. Am. J. Physiol. Endocrinol. Metab. 305:E416-E428.

Larsen, M., and N. B. Kristensen. 2013. Precursors for liver gluconeogenesis in periparturient dairy cows. Animal 7:1640-1650.

Lee, C., A. N. Hristov, C. J. Dell, G. W. Feyereisen, J. Kaye, and D. Beegle. 2012. Effect of dietary protein concentration on ammonia and greenhouse gas emitting potential of dairy manure. J. Dairy Sci. 95:1930-1941.

Millward, D. J., M. M. Jepson, and A. Omer. 1989. Muscle glutamine concentration and protein turnover in vivo in malnutrition and in endotoxemia. Metabolism 38:6-13.

Nandi, D., P. Tahiliani, A. Kumar, and D. Chandu. 2006. The ubiquitin-proteasome system. J. Biosci. 31:137-155.

Narita, M., and K. Inoki. 2012. Rags connect mTOR and autophagy. Small GTPases 3:111-114.

NRC. 2001. Nutrient Requirements of Dairy Cattle. 7th rev. ed. Natl. Acad. Sci., Washington, DC.

Proud, C. G. 2006. Regulation of protein synthesis by insulin. Biochem. Soc. Trans. 34:213-216.

Sancak, Y., L. Bar-Peled, R. Zoncu, A. L. Markhard, S. Nada, and D. M. Sabatini. 2010. Ragulator-Rag complex targets mTORC1 to the lysosomal surface and is necessary for its activation by amino acids. Cell 141:290-303.

Sarbassov, D. D., D. A. Guertin, S. M. Ali, and D. M. Sabatini. 2005. Phosphorylation and regulation of Akt/PKB by the rictor-mTOR complex. Science 307:1098-1101.

Saremi, B., H. Sauerwein, S. Dänicke, and M. Mielenz. 2012. Technical note: Identification of reference genes for gene expression studies in different bovine tissues focusing on different fat depots. J. Dairy Sci. 95:3131-3138.

SAS Institute. 2012. SAS/STAT User's Guide. Release 9.4, SAS Inst. Inc., Cary, NC.

Schulman, B. A., and J. W. Harper. 2009. Ubiquitin-like protein activation by E1 enzymes: the apex for downstream signaling pathways. Nat. Rev. Mol. Cell Biol. 10:319-331.

Schwab, C. G., and R. S. Ordway. 2004. Balancing diets for amino acids: implications of production efficiency and feed costs. Pages 1-16 in Proc. Penn State Dairy Cattle Nutr. Workshop, Grantville, PA. The Pennsylvania State University, University Park.

Stroup, W. W. 2012. Generalized Linear Mixed Models: Modern Concepts, Methods and Applications. Chapman \& Hall/CRC Texts in Statistical Science, London, UK.

Suryawan, A., P. M. O'Connor, J. A. Bush, H. V. Nguyen, and T. A. Davis. 2009. Differential regulation of protein synthesis by amino acids and insulin in peripheral and visceral tissues of neonatal pigs. Amino Acids 37:97-104.

Environmental Protection Agency (US EPA). 2011. Reactive Nitrogen in the United States: An Analysis of Inputs, Flows, Consequences, and Management Options. A Report of the EPA Science Advisory Board (EPA-SAB-11-013). EPA, Washington, DC.

van der Drift, S. G., M. Houwelling, J. T. Schonwellie, A. G. Tielens, and R. Jorritsma. 2012. Protein and fat mobilization and associations with serum $\beta$-hydroxybutyrate concentrations in dairy cows. J. Dairy Sci. 95:4911-4920.

Vandesompele, J., K. De Preter, F. Pattyn, B. Poppe, N. Van Roy, A. De Paepe, and F. Speleman. 2002. Accurate normalization of real-time quantitative RT-PCR data by geometric averaging of multiple internal control genes. Genome Biol. 3:research0034.1-research0034.11.

Wu, G., F. W. Bazer, G. A. Johnson, D. A. Knabe, R. C. Burghardt, T. E. Spencer, X. L. Li, and J. J. Wang. 2011. Triennial Growth Symposium: important roles for L-glutamine in swine nutrition and production. J. Anim. Sci. 89:2017-2030.

Wullschleger, S., R. Loewith, and M. N. Hall. 2006. TOR signaling in growth and metabolism. Cell 124:471-484.

Yang, X., C. Yang, A. Farberman, T. C. Rideout, C. F. M. de Lange, J. France, and M. Z. Fan. 2008. The mammalian target of rapamycin-signaling pathway in regulating metabolism and growth. J. Anim. Sci. 86:E36-E50. 